\title{
Pelatihan Penerapan PP No 23 Tahun 2018 dan Aspek Perpajakannya di Lingkungan SMKN 44 Jakarta Pusat
}

\author{
Agustina Indriani $^{1}$, Ahmad Basid Hasibuan ${ }^{2}$, Jombrik TPR ${ }^{3}$, Sri Ari Wahyuningsih ${ }^{4}$ \\ Akuntansi, Ekonomi, Universitas Darma Persada, Jakarta, Indonesia \\ Email: 1agustinareni81@gmail.com, ${ }^{2}$ basid_unsada@yahoo.co.id, ${ }^{3}$ brikradha@yahoo.co.id, \\ 4ari_unsada@yahoo.com
}

\begin{abstract}
Abstrak
The purpose of implementing the service is to provide a broader understanding to the community, especially to students in the SMKN 44 Central Jakarta environment. With this activity, students/trainees have skills that can be used if they want to work after graduating from SMKN. This training on taxation is indeed very important and needed at this time by teachers and students at SMKN 44 Central Jakarta where the material provided is up to date taxation in accordance with current government regulations including incentives provided by the government in conditions the Covid-19 pandemic. The results of this training also obtained an illustration that socialization of taxation for MSMEs must continue to be carried out by related parties so that all levels of society can understand and understand their tax obligations. The implementation of this learning shows that the enthusiasm of students and teachers for the material presented is quite high and it is very much needed for students and teachers, it is proven that many participants ask questions about the material presented and taxation in general, but due to time constraints so not all of the participants' questions can be answered one by one. This can be interpreted that the participants listened carefully to all the material presented.
\end{abstract}

Keyword : Training, Application of PP No. 23 of 2018, Taxation Aspects

\begin{abstract}
Abstrak
Tujuan pelaksanaan pengabdian adalah untuk memberikan pemahaman yang lebih luas kepada masyarakat khusunya kepada para pelajar dilingkungan SMKN 44 Jakarta pusat. Dengan kegiatan ini juga para pelajar/peserta pelatihan memiliki bekal ketrampilan yang dapat menjadi bekal apabila berkeinginan untuk bekerja setelah lulus dari SMKN. Pelatihan mengenai perpajakan ini memang sangat penting dan dibutuhkan saat ini oleh guru dan siswa di SMKN 44 Jakarta Pusat di mana materi yang di berikan merupakan perpajakan yang sudah up to date sesuai dengan peraturan pemerintah yang berlaku saat ini termasuk insentif yang di berikan oleh pemerintah dalam kondisi pandemic Covid -19. Hasil pelatihan ini juga diperoleh gambaran bahwa sosialisasi perpajakan bagi UMKM harus terus dilakukan oleh pihak pihak terkait agar seluruh lapisan masyarakat dapat mengerti dan memahami kewajiban perpajakannya.
\end{abstract}

Kata Kunci: Pelatihan, Penerapan PP No 23 Tahun 2018, Aspek Perpajakan

\section{A. PENDAHULUAN}

Dalam beberapa tahun terakhir sektor Usaha Mikro Kecil Menengah (UMKM) telah berhasil menjelma menjadi sumber penggerak ekonomi baru di Indonesia. Kontribusi UMKM terhadap Produk Domestik Bruto (PDB) tercatat mencapai 61,41 persen. Dengan dominasi tersebut, UMKM setidaknya menyerap hampir 97 persen total tenaga kerja nasional dan memiliki proporsi 99 persen dari total pelaku usaha di Indonesia. UMKM saat ini merupakan bidang usaha yang menjadi perhatian khusus dari pemerintah, hal ini bukan tanpa alasan tapi fakta dalam beberapa dekade terakhir membuktikan bahwa bidang usaha UMKM mampu bertahan dalam berbagai situasi ekonomi yang tidak baik atau dalam situasi krisis. Dalam situasi krisis ekonomi yang melanda dunia termasuk Indonesia industri berskala besar banyak yang kalaps namun tidak dialami oleh sebagian besar UMKM yang tetap mampu bertahan. Eksistensi UMKM mampu mendorong percepatan pemulihan ekonomi secara nasional.

Tidak berlebihan apabila kita menyebut bahwa ekonomi di Indonesia tumbuh pesat lewat sektor 
UMKM. Peran UMKM terhadap perekonomian dan penyerapan tenaga kerja memang tidak lagi diragukan. Namun, dalam sektor perpajakan, UMKM belum mencerminkan kontribusi yang dominan sebagaimana pengaruhnya terhadap perekonomian dan penyerapan tenaga kerja. Pada tahun 2014, sumbangsih penerimaan pajak dari $\mathrm{PPh}$ Final UMKM hanya sekitar Rp 2 triliun. Dengan asumsi UMKM berkontribusi Rp.3.000 trilliun terhadap PDB, nilai itu masih relatif jauh dibawah potensi perpajakan sebesar Rp 30 triliun (1 persen dari kontrobusi terhadap PDB). Dalam pembagunan ekonomi Nasional, UMKM memiliki peran penting dan strategis. UMKM secara nyata dapat menyerap tenaga kerja selama kurun waktu 1 dekade terakhir. Namun hal ini tidak terefleksi pada aspek perpajakannya. Menurut data yang dirilis Ditjen Pajak, di tahun 2017 penerimaan PPH final UMKM hanya berkisar 2,2\% dari total penerimaan PPh yang dibayarkan oleh wajib pajak.

Untuk itu, menggali potensi penerimaan pajak UMKM merupakan salah satu fokus kerja Kementerian Keuangan (Kemenkeu). Guna mencapai tujuan itu, Kemenkeu terus berupaya meningkatkan tingkat partisipasi pajak UMKM dengan menciptakan ekosistem perpajakan yang ramah. Pemetaan perpajakan yang mudah bagi UMKM pun terus disusun. Lalu langkah nyata apa saja yang telah pemerintah lakukan guna mendorong tingkat kontribusi UMKM terhadap pajak ?(Keuangan), 2018)

\section{B. PELAKSAAAN DAN METODE}

Metode yang akan dilakukan dalam kegiatan pengabdian pada masyarakat ini berdasarkan pada target luaran dan solusi yang ditawarkan. Metode yang digunakan adalah berupa pelatihan yaitu pelatihan menghitung pajak UMKM. Adapun tahapan yang dilakukan adalah

(1) dilakukan pre test terhadap seluruh peserta untuk mengetahui sejauhmana pengetahuan mereka tentang pajak UMKM

(2) Memberikan gambaran tentang perpajakan secara umum dan PP N0 23 tahun 2018 yang terkait dengan pajak UMKM melalui penjelasan dan tanya jawab

(3) Pelatihan perhitungan Pajak UMKM

(4) Melakukan post test kepada seluruh peserta guna mengetahui pemahaman hasil pelatihan yang diberikan.

Oleh karena pelaksanaan pengabdian ini dilakukan dimasa pandemic covid 19 maka seluruh kegiatan dilaksanakan melalui platform Zoom Meeting.

Pelaksanaan kegiatan dilakukan melalui beberapa tahap

- Diawali dengan melakukan komunikasi dengan pihak sekolah untuk menyampaikan maksud dan

\section{tujuan kegiatan}

- Melakukan koordinasi dengan pihak sekolah untuk menghimpun peserta yaitu para pelajar SMKN 44 Jakarta Pusat.

- Penyebaran flyer untuk pendaftaran melalui link ://bit.ly/PelatihanPajakdiSMK44.

- Pelaksanaan pelatihan dengan melakukan presentasi memberikan teori dan penjelasan, kemudian dilanjutkan untuk diskusi dengan para peserta, selanjutnya melakukan praktek penghitungan pajak UMKM sesuai PP 23 tahun 2021

Adapun pelaksanaan kegiatan ini adalah:

Hari/Tanggal : Rabu 28 Juli 2021

Pukul : 09 WIB s/d 15.30

Peserta : Para guru dan siswa kelas XI dan XII Jurusan Akuntansi di SMKN 44 Jakarta Pusat. (9 Guru dan 232 murid)

Tempat kegiatan: Link Zoom

Agustina Indriani is inviting you to a scheduled Zoom meeting.

Topic: PELATIHAN PP No 23 TAHUN 2018 DAN ASPEK PERPAJAKANNYA DI LINGKUNGAN SMKN 44 JAKARTA PUSAT

Time: Jul 28, 2021 07:30 AM Bangkok

Join Zoom Meeting https://zoom.us/j/94473135750?pwd=MktzRHRq d2dPZXA1T2NFNEQ5UmxyQT09

Meeting ID: 94473135750

Passcode: 595933

\section{HASIL DAN PEMBAHASAN}

Sesuai dengan rancangan kegiatan yang disiapkan yaitu diawali pre test yang dilakukan sebelum pelatihan memperlihatkan bahwa pendaftar tertarik untuk untuk mengikuti pelatihan, dari hasil pre test ini juga diketahui bahwa para peserta sebagian besar belum mengetahui tentang peraturan pemerintah no 23 tahun 2018 termasuk pelaksanaannya sehingga dapat disimpulkan bahwa pelatihan ini memang penting bagi mereka.

Dengan adanya hasil pre test tersebut maka pelaksanaan pelatihan pengabdian ini akhirnya hanya difokuskan pada pajak UMKM dengan harapan peserta betul-betul memahaminya. Materi perpajakan yang disampaikan adalah berupa peraturan perpajakan yang berhubungan dengan wajib pajak UMKM. Dalam pelatihan ini dijelaskan mengenai kewajiban perpajakan UMKM yang dikaitkan dengan besarnya omzet dari UMKM tersebut.

\section{Materi yang disampaikan meliputi}

a. Pengenaan pajak bagi UMKM dengan omzet < 4,8 milyar yaitu UMKM yang memiliki omzet di bawah 4,8 M hanya memiliki kewajiban 
membayar pajak penghasilan dengan tarif sesuai dengan ketentuan PP No 23 Tahun 2018 yaitu pajak final dengan tarif $0,5 \%$ dari omzet.(Indonesia, 2018)

b. Pengenaan pajak bagi UMKM dengan omzet 4,8 sampai dengan 50 milyar. yaitu UMKM yang memiliki omzet 4,8 milyar - 50 milyar memiliki kewajiban membayar pajak penghasilan dengan tarif sesuai dengna ketentuan UU Pajak penghasilan pasal 34 (untuk WP Badan) dan pasal 17 (untuk WP OP) dan segala ketentuan peraturan perundangan yang berhubungan dengan pajak penghsailan termasuk pemungutan PPN.

c. Pengenaan pajak bagi UMKM dengan omzet diatas 50 milyar yaitu UMKM yang memiliki memiliki kewajiban membayar pajak penghasilan dengan tarif sesuai dengna ketentuan UU Pajak penghasilan pasal 17 dan segala ketentuan peraturan perundangan yang berhubungan dengan pajak penghsailan termasuk pemungutan PPN. (Syaputra, 2019)

Setelah pemberian materi tersebut diatas dilanjutkan dengan tanya jawab dengan peserta dilanjutkan dengan mempraktekkan tentang perhitungan pajak penghasilan bagi UMKM dengan focus utama pada PP No 23 Tahun 2018 yaitu pajak final dengan tarif $0,5 \%$ dari omzet. baik secara manual maupun dengan system online mulai dari pembuatan surat setoran pajak sampai dengan pelaksanaan pembayarannya.

Tahap selanjutnya dilakukan post test dengan tujuan untuk mengetahui sejauhmana peserta mengerti dan mampu menerapkan hasil pelatihan tersebut. Dari jumlah peserta sebanyak 241 (9 guru dan 232 Siswa) dari hasil Post test diketahui bahwa sebagian besar menyatakan sangat tertarik dengan materi pelatihan yang disampaikan, juga diketahui bahwa setelah pelatihan mereka akhirnya dapat mengerti tentang pajak UMKM.

Pelaksanaan pembelajaran ini menunjukkan bahwa antusias dari siswa dan guru terhadap materi yang disajikan cukup tinggi dan ternyata sangat dibutuhkan bagi para siswa dan guru, terbukti peserta banyak yang mengajukan pertanyaan seputar materi yang disampaikan dan perpajakan secara umum, namun karena keterbatasan waktu sehingga tidak semua pertanyaan peserta dapat dijawab satu persatu. Hal ini dapat diartikan bahwa peserta menyimak dengan baik seluruh materi yang disampikan. Materi yang diampaikanpun merupakan bagian dari materi pembelajaran dalam kurikulum SMK Negeri 44 Jakarta Pusat, hanya saja perlu pendalaman materi kepada siswa baik itu perhitungan, peraturan dan jenis usahanya. Termasuk juga pelaporan dan pembayaran kepada kas negara.
Pemerintah disarankan mengintensifkan sosialisasi pengenaan pajak usaha kecil dan menengah (UKM) yang berlaku mulai 1 Juli 2013. Pasalnya, sebagian besar pelaku UKM belum paham dengan pajak yang bernaung di Peraturan Presiden (Perpres) No 46/2013 itu. Selain itu, masih terdapat banyak hambatan dalam penerapan perpres tersebut. Wakil Ketua Umum Kamar Dagang dan Industri (Kadin) Bidang UKM dan Koperasi, Erwin Aksa, mengatakan sekitar 60-70 persen pelaku UKM belum tahu pengenaan pajak sebesar 1 persen dari omzet per bulan tersebut. Demikian pula dengan peraturan pemerintah no 23 tahun 2018 (PP 23/2018) yang merupakan revisi dari Peraturan Pemerintah No.46 Tahun 2013 yang mengatur tentang pajak penghasilan atas penghasilan dari usaha yang diterima atau diperoleh wajib pajak yang memiliki peredaran bruto tertentu, juga belum tersosialisasi dengan baik terhadap pelaku wajib pajak. (Indonesia, 2018)

Banyak pelaku usaha UMKM yang mungkin menganggap kewajiban pajak sebagai beban sehingga berusaha uuntuk menghindarinya namun tidak sedikit pula yang bersedia membayar pajak namun mereka tidak mengerti tatacara dan mekanisme perhitungannya. Pelaksaanaan kegiatan pengabdian masyarakat ini merupakan salah satu upaya membantu pemerintah dalam rangka sosialisasi perpajakan bagi masyarakat yang dalam kesempatan ini dilakukan terhadap pelajar dan guru guru di SMKN 44 Jakarta Pusat, dengan harapan bahwa lulusan SMKN yang lulus dan terjun kedalam dunia kerja dilingkungan UMKM memiliki kemampuan menghitung pajak khusunya pajak yang diatur dalam PP 23 tahun 2018 tersebut.

Pajak menurut Soemitro dalam (Mardiasmo, 2019 , p. 3) pajak adalah iuran rakyat kepada kas negara berdasarkan undang-undang (yang dapat dipaksakan) dengan tidak mendapat jasa timbal (kontraprestasi) yang langsung dapat ditunjukkan dan yang digunakan untuk membayar pengeluaran umum. Adapun Fungsi Pajak menurut (Mardiasmo, 2019, p. 4) ada dua fungsi pajak. Pertama, fungsi anggaran (budgetair) yaitu pajak berfungsi sebagai salah satu sumber dana bagi pemerintah untuk membiayai pengeluaran-pengeluarannya. Kedua, fungsi mengatur (regulerend) yaitu pajak berfungsi sebagai alat untuk mengatur atau melaksanakan kebijaksanaan pemerintah dalam bidang sosial dan ekonomi.

Jenis Pajak dalam (Siti Resmi, 2019, p. 7) terdapat tiga jenis pajak yaitu, pajak menurut golongan terdiri atas pajak langsung dan pajak tidak langsung, pajak menurut sifat terdiri atas pajak subjektif dan pajak objektif, dan pajak menurut lembaga pemungut terdiri atas pajak negara dan pajak daerah.

Pajak Penghasilan Menurut (Mardiasmo, 2019, p. 153) mengatakan bahwa UU PPh mengatur 
tentang pengenaan pajak penghasilan terhadap subjek pajak berkenaan dengan penghasilan yang diterima atau diperoleh dalam tahun pajak. sedangkan dalan pasal 4 ayat (1) UU No.36 Tahun 2008 mendefinisikan bahwa objek pajak penghasilan, yaitu setiap tambahan kemampuan ekonomis yang diterima atau diperoleh wajib pajak, yang berasal dari Indonesia ataupun luar Indonesia, yang dapat digunakan untuk konsumsi atau menambah kekayaan wajib pajak dengan nama dan dalam bentuk apapun, sedangkan akuntansi pajak menurut (waluyo, 2020, p. 153) yaitu dalam menetapkan besarnya pajak terutang tetap mendasarkan laporan keuangan yang disusun oleh perusahaan, mengingat tentang perundangundangan perpajakan terdapat aturan-aturan khusus yang berkaitan dengan akuntansi, yaitu masalah konsep transaksi dan peristiwa keuangan, metode pengukurannya, serta pelaporan yang ditetapkan dengan undang-undang

\section{Sosialisasi Pajak UMKM}

Menurut Erwin, pemerintah sebaiknya mengintensifkan sosialisasi pajak UKM, terutama terkait administrasi pencatatannya. "Seperti apa pembukuan dan pencatatan macam apa yang dibutuhkan. Saya khawatir pelaku UKM-nya kagetkaget dikenakan pajak," kata dia. Erwin memperkirakan aturan ini akan terkendala beberapa hal utamanya penjaringan dan pendataan nasabah pajak UKM yang saat ini datanya tersebar di beberapa instansi. "Collection dan pendataan wajib pajak UKM ini tidak gampang, apalagi untuk usaha yang omzet usaha rendah masih berada jauh di level 4,8 M pertahun atau di bawah 4 miliar rupiah per tahun. Sebagian besar pelaku UKM, kata dia, belum memiliki pem-bukuan dan pencatatan transaksi yang rapi karena biasanya hanya mencatat jumlah barang yang masuk dan keluar. Sebelumnya, sejumlah kalangan, seperti Himpunan Pengusaha Pribumi Indonesia (HIPPI) DKI Jakarta Kadin Jawa Barat, dan pengamat menolak pengenaan pajak bagi UKM tersebut. Mereka menilai bahwa kebijakan itu tidal adil dan akan semakin menurunkan daya saing UKM.

Menanggapi penolakan tersebut Direktur Jenderal Pajak Fuad Rahmany, justru meng-ancam akan menaikkan pajak kepada para UKM. Apabila para pelaku usaha menolak pemberlakuan pajak UKM sebesar 1 persen dari omzet bulanan tersebut justru para pelaku usaha akan dikenakan tarif pajak umum yang nilainya lebih mahal dan memberatkan," tegas dia.

Fuad menilai saat ini banyak pelaku usaha beromzet di bawah 4,8 miliar rupiah, yang sebenarnya sangat mampu bahkan kaya, namun bersembunyi dibalik $\log 0$

UKM.

Dia menegaskan bahwa pemberlakuan pajak UKM dilakukan untuk mengedepankan masalah keadilan
Buruh pabrik yang jauh lebih rendah'pendapatannya saja sudah membayar pajak Lalu apakah adil bila buruh sudah bayar pajak tetapi mereka tidak mau bayar pajak padahal omzet para pengusaha UMKM jauh lebih tinggi daripada buruh dimana UMKM ada penghasilannya bisa beromzet yang miliaran dalam setahun. Maka ini perlu ada keadilan dalam hal pembayaran pajak. Fuad kembali menegaskan bahwa UKM yang terkena $\mathrm{PPh}$ adalah para pelaku UKM yang memiliki tempat usaha yang kini jumlahnya jutaan. "PPh ini tidak dikenakan terhadap pedagang keliling yang melakukan kegiatan usaha perdagangan dengan tidak menetap, pedagang asongan, dan warung tenda di trotoar, industri rumahan, start-up yang melakukan bisnis online jelas dia. ((kementerian perindustrian), 2013)

Direktur Jenderal Industri Kecil dan Menengah Kementerian Perindustrian, Euis Saedah, meyakini bahwa UMKM akan mampu bangkit meskipun pemerintah telah memutuskan untuk memungut pajak bagi usaha yang memiliki omzet kurang dari 4,8 miliar rupiah per tahun. Dalam hal pajak penghasilan atas UMKM yang tertuang dalam Peraturan Pemerintah (PP) No: 23 Tahun 2018 ini menurunkan tarif pajak yang semula sebesar $1 \%$ menjadi $0,5 \%$. Adapun tarif pajak ini dikenakan atas peredaran bruto sesuai prinsip presumptive tax, yakni perhitungan nilai pajak terutang berdasarkan indikator selain penghasilan neto. Penerapan presumptive tax ini bertujuan untuk menjamin kemudahan administrasi pajak oleh pelaku UMKM dengan penyederhanaan perhitungan pajak.

Selain itu, menciptakan perpajakan yang ramah bagi UMKM bukan hanya dilakukan dengan memberikan tarif pajak yang rendah. Inovasi yang dikembangkan oleh Pemerintah adalah menciptakan aplikasi perpajakan bagi UMKM yang memiliki fungsi untuk merekapitulasi pendapatan UMKM sekaligus sebagai kasir online. Aplikasi pintar tersebut juga diciptakan agar mampu terintegrasi dengan perhitungan dan pembayaran PPH Final bagi UMKM.

Tujuan dari aplikasi perpajakan bagi UMKM tersebut adalah untuk memudahkan pengusaha UMKM dalam mengenali omzet usahanya, memberikan kepraktisan pembukuan, hingga kemudahan perhitungan perpajakan bagi usaha mereka. Saat ini, Kemenkeu melalui Direktorat Jenderal Pajak telah menggandeng empat perusahaan sebagai penyedia jasa aplikasi perpajakan atau Application Service Provider (ASP). Diharapkan aplikasi digital ini dapat memangkas beragam kesulitan mitra UMKM selama ini dalam perhitungan dan pembayaran pajak. 
Dalam menjalin suatu tujuan bersama dibutuhkan sinergitas dan komunikasi yang baik untuk menjalin hubungan timbal baik yang apik secara langsung bersama UMKM. Langkah tersebut dilakukan Kemenkeu dengan cara memberikan asistensi perpajakan, menciptakan layanan komunikasi yang responsif, serta inovasi dengan menggandeng UMKM. Upaya-upaya tersebut dibangun baik secara masif maupun secara inisiatif melalui kantor-kantor pelayanan pajak. Misalnya Kantor Pelayanan Pajak Palmerah yang mengadakan seminar pelatihan usaha bagi UMKM. Kemudian KPP Madiun dengan menyediakan "Pojok UMKM", yaitu sebuah etalase yang memamerkan produk UMKM yang ada di Kota Madiun dan sekitarnya. Masyarakat yang tertarik dengan produk yang ditampilkan dapat menghubungi contact center produk yang ada dalam "Pojok UMKM" tersebut.

Langkah dalam menciptakan perpajakan yang ramah juga disambut baik oleh Direktorat Jenderal Bea dan Cukai dengan memberikan fasilitas Kemudahan Impor Tujuan Ekspor untuk Industri Kecil Menengah (KITE IKM) guna mendorong UMKM menembus pasar global. Melalui fasitias ini, saat mengimpor barang modal dan bahan baku guna membuat produk untuk diekspor, industri kecil menengah diberikan pembebasan bea masuk, Pajak Pertambahan Nilai (PPN), dan Pajak Penjualan atas Bawang Mewah (PPnBM). Hal ini bertujuan untuk menciptakan iklim produksi impor-ekspor yang ringan bagi UMKM.

Langkah-langkah tesebut merupakan wujud nyata untuk menciptakan pajak yang ramah bagi mitra UMKM. Dengan berbasis rasa saling percaya dan semangat kontribusi itulah, pajak menjadi instrumen dalam mendorong perekonomian nasional. Dan dalam sektor UMKM, pajak mencoba hadir secara membumi bagi UMKM. Sehingga diharapkan mampu meningkatkan UMKM untuk tidak hanya ada dominan dalam mengembangkan perekonomian bangsa namun juga bisa memberikan sumbangsihnya untuk turut bergotong-royong membangun negara yang adil, makmur, dan berdaulat, melalui pajak.(Keuangan), 2018)

Peraturan Pemerintah No.23 Tahun 2018 (PP 23/2018) merupakan revisi dari Peraturan Pemerintah No.46 Tahun 2013 yang mengatur tentang pajak penghasilan atas penghasilan dari usaha yang diterima atau diperoleh wajib pajak yang memiliki peredaran bruto tidak lebih dari Rp 4,8 M dalam satu tahun pajak, dan mulai diberlakukan secara efektif pada tanggal 1 Juli 2018. Dalam Christian (2019) terdapat pokok-pokok penting yang diatur dalam PP 23/2018, yaitu (1) tarif $\mathrm{PPh}$ Final $0,5 \%$ bersifat opsional; (2) tarif PPh Final sesuai ketentuan PP 23/2018 memiliki batas waktu; (3) omset/ peredaran bruto yang dikenakan kepada wajib pajak UMKM yaitu di bawah Rp 4,8 Miliar dalam satu tahun; (4) wajib pajak yang tidak bisa mengenakan PPh final sesuai ketentuan PP 23/2018 adalah wajib pajak orang pribadi yang memperoleh penghasilan dari usaha jasa sehubungan dengan pekerjaan bebas, wajib pajak dengan penghasilan yang berasal dari luar negeri yang memiliki pajak terutang atau yang telah dibayar di luar negeri, wajib pajak yang telah dikenakan pajak penghasilan yang bersifat final lainnya, dan wajib pajak yang memperoleh penghasilan yang tidak termasuk sebagai objek pajak

Penerapan Peraturan Pemerintah Nomor 23 Tahun 2018 (Indonesia, 2018) dilaksanakan mulai dari pertengahan tahun 2018 yaitu pada bulan Juli 2018. PP Nomor 23 Tahun 2018 adalah peraturan mengenai penghasilan atau pendapatan dari usaha yang diperoleh wajib pajak yang memilik peredaran bruto tertentu dalam satu tahun masa pajak. PP ini berlakum mulai 1 Juli 2018. Adapun tarif pajak penghasilan yang baru bagi UMKM sebesar 0,5 persen dari omset. Peraturan tersebut menggantikan peraturan sebelumnya, yaitu PP No.46 tahun 2013 dengan tarif $\mathrm{PPh}$ final UMKM sebesar 1 persen yang dihitung berdasarkan pendapatan bruto (omzet)-nya diperuntukkan bagi UMKM yang beromzet kurang dari Rp 4,8 miliar dalam setahun (Keuangan), 2013)

\section{PENUTUP}

\section{Simpulan}

Setelah pelaksanan pelatihan dalam rangka pengabdian masyarakat dapat diambil kesimpulan:

1. Pelatihan mengenai perpajakan ini memang sangat penting dan dibutuhkan oleh guru dan siswa di SMKN 44 Jakarta Pusat sebagai pengetahuan dan bekal bila mereka bekerja atau membuka usaha karena materi yang di berikan merupakan perpajakan yang sudah up to date sesuai dengan peraturan pemerintah yang berlaku saat ini termasuk insentif yang di berikan oleh pemerintah dalam kondisi pandemic Covid $-19$

2. Setelah pelatihan para peserta Sebagian besar akhirnya mengerti dan dapat menghitung pajak UMKM khususnya yang terkait dengan PP no 23 tahun 2018

\section{Saran}

Pelatihan semacam ini perlu dilakukan sebagai sarana pengabdian masyarakat untuk memberikan pembelajaran kepada masyarakat/siswa sebagai bekal bila mana mereka bekerja pada bidang perpajakan atau membuka usaha.

\section{E. DAFTAR PUSTAKA}

(kementerian perindustrian). (2013). Pajak UKM 


\section{Minim}

Sosialisasi.

https://kemenperin.go.id/artikel/6687/-PajakUKM-Minim-Sosialisasi

Indonesia, P. R. (2018). Pajak Penghasilan Atas Penghasilan Dari Usaha Yang Diterima Atau Diperoleh Wajib Pajak Yang Memiliki Peredaran Bruto Tertentu. Peraturan Pemerintah No. 23 Tahun 2018, 1-9.

Keuangan), (Kementerian. (2013). Pengenaan PPh atas Usaha dengan Omzet Tertentu pada 1 Juli 2013

https://www.kemenkeu.go.id/publikasi/berita /pengenaan-pph-atas-usaha-dengan-omzettertentu-pada-1-juli-2013/

Keuangan), (Kementerian. (2018). Menciptakan Pajak yang Ramah untuk UMKM. https://www.kemenkeu.go.id/publikasi/artike 1-dan-opini/menciptakan-pajak-yang-ramahuntuk-umkm/

Mardiasmo. (2019). Perpajakan. Andi Offset.

Siti Resmi. (2019). Perpajakan Teori dan Kasus. Salemba Empat.

Syaputra, R. (2019). Pengaruh Persepsi Wajib Pajak atas Penerapan Peraturan Pemerintah Nomor 23 Tahun 2018 dan Pemahaman Perpajakan Terhadap Kepatuhan Wajib Pajak Usaha Mikro, Kecil, dan Menengah dengan Sosialisasi Perpajakan Sebagai Variabel Moderasi. Jurnal Magister Akuntansi Trisakti. Https://Doi. Org/10.25105/Jmat. V6i2, 5560.

waluyo. (2020). Perpajakan Indonesia. Salemba Empat. 